\title{
A Content analysis of graduate theses concerning early childhood education in Turkey
}

\author{
Seden Demirtaș İlhan ${ }^{(1)}$ \\ Artvin Çoruh University, Faculty of Education, Artvin, Turkey, demirtasseden@ gmail.com \\ https://orcid.org/0000-0003-2447-8482 \\ Feyza Tantekin Erden ${ }^{(1)}$ \\ Middle East Technical University, Faculty of Education, Ankara, Turkey tfeyza@metu.edu.tr \\ https://orcid.org/0000-0001-6060-1877
}

\begin{abstract}
This study aims to investigate the descriptive characteristics, research topics and methodological procedures of master's theses and doctoral dissertations regarding early childhood education in Turkey. Within the scope of the current study, 931 Master's theses and 171 doctoral dissertations were analyzed according to university, institute, department, publication year, academic title of the advisor, research topic, sample group, location in which the study took place, research setting of the study, type of research, instruments, statistical analysis, and sampling methods. The study covers theses published from 1986 to 2016, and a content analysis method was implemented for data analysis. As expected, the current study found that students were the most frequently used subject groups in both MS theses $(37.39 \%)$ and $\mathrm{PhD}$ dissertations (53.39\%). In the MS theses, researchers mostly preferred research topics regarding the education of young children (29.95\%) whereas in $\mathrm{PhD}$. dissertations, researchers mainly focused on developmental issues $(32.78 \%)$. Nearly, all the graduate theses were conducted in city centers and central districts.
\end{abstract}

Keywords: $\quad$ Early childhood education, Content analysis, Graduate education, Graduate theses, Theses examination

\section{Türkiye'deki erken çocukluk eğitimi üzerine yazılmış lisansüstü tezlerin bir içerik analizi}

ÖZ Bu çalışma, Türkiye'deki erken çocukluk eğitimi üzerine yazılmış, yüksek lisans ve doktora tezlerinin betimsel özelliklerini, araştırma konularını ve metodolojik yöntemlerini incelemeyi amaçlamaktadır. Bu çalışma çerçevesinde, 931 yüksek lisans ve 171 doktora tezi, üniversite, enstitü, bölüm, yayınlanma tarihi, danışmanın akademik unvanı, araştırma konusu, örneklem grubu, araştırmanın gerçekleştirildiği mekân, çalışmanın araştırma düzeneği, araştırma türü, kullanılan araçlar, istatiksel analiz ve örnek alma yöntemi açısından analiz edilmiştir. Mevcut çalışma 1986-2016 yılları arasında yayınlanan lisansüstü tezleri kapsamaktadır. Çalışmada veri analizi yöntemi olarak içerik analizi uygulanmıştır. Güncel araştırmanın verileri göstermiştir ki, hem yüksek lisans $(\% 37,39)$ hem de doktora tezlerinde $(\% 53,39)$, öğrencilerin en sık kullanılan denek grubu olduğunu göstermiş̧ir ki, bu beklenen bir bulgudur. Yüksek lisans tezlerinde, araştırmacılar çoğunlukla $(\% 37,39)$ küçük yaştaki çocukların eğitimi üzerine araştırma konularını seçerken, doktora tezlerinde araştırmacılar, genellikle $(\% 32,78)$ gelişimsel konulara odaklanmıştır. Neredeyse tüm lisansüstü tezler, şehir merkezlerinde veya merkezi ilçelerde gerçekleştirilmiştir.

Anahtar Kelimeler:

Erken çocukluk eğitimi, İçerik analizi, Lisansüstü eğitim, Lisansüstü tezler, Tez inceleme

Citation: $\quad$ Demirtaş İlhan, S. \& Tantekin Erden, F. (2019). A Content analysis of graduate theses concerning early childhood education in Turkey. Turkish Journal of Education, 8(2), 86-108. https://dx.doi.org/10.19128/turje.489226 


\section{INTRODUCTION}

Although the definition of education has changed over the years, it basically refers to "...the process of facilitating learning which has been an integral part of human societies since before we were even human" (The Worldwatch Institute, 2017). Since ancient times, enabling people to reach their full potential has been one of the ongoing purposes of education. Moreover, providing intellectual development, meeting social needs, contributing to the economy, creating an effective workforce, providing job and career opportunities for students, and enhancing political and economic systems are the other widely accepted purposes of education. According to Foshay (1991), the broadest educational purpose statement covers all of these aspects and seeks to contribute to all domains of human experience (as cited in Brandt, 2000).

Graduate education constitutes the last stage of formal education and these programmes are managed by graduate schools offering master's and doctoral degree programmes which include both research and coursework. Graduate education differs from undergraduate education in terms of training and instruction. Undergraduate classes comprise larger groups, but graduate education appeals to smaller groups in which individual effort and self-directed learning are essential. Deeper training is provided in graduate education with increased specialization (Targonski, 2003). To this end, graduate education provides more specialized education in a particular field or a sub-field. Furthermore, a well-qualified graduate education programme improves participants' skills of problem solving, academic writing, oral presentation, and technology use (Ebel, n.d.).

Master of Arts or Doctor in Philosophy (in the field of education) degrees do not require one to be a teacher in most countries, but many inspiring teachers (enthusiastic) opt to pursue an advanced degree in a sub-specialty of education (Feiman-Nemser, 1989). Undertaking an advanced degree in early childhood education is a good way to enhance professional knowledge and career potential. Moreover, a graduate degree in early childhood education provides various opportunities for teachers to apply not only in the classroom environment but also outside the classroom. Having a graduate degree in early childhood education is an integral part of a career in academia and preparation for positions as an administrator or a lead teacher in early childhood education settings. Furthermore, these graduate programmes enable teachers to promote learning and development in young children from diverse cultural backgrounds and have different abilities in preschool settings (Guha, n.d.).

An advanced degree programme in early childhood education includes coursework and activities. Additionally, conducting original research in the form of a master's thesis and doctoral dissertation is a common requirement. The purpose of engaging in a graduate thesis is to equip students with specialized skills and advanced knowledge in early childhood pedagogy, technology, administration, community collaboration, and policy analysis [The National Institute for Early Education Research (NIEER), 2017].

Graduate studies also enhance the literature of the studied field. According to Jin (2004), graduate studies contain valuable knowledge, produced by scholars and experts in the field. Moreover, the studies assessed in the current work shed light on the amount of research that has been conducted to date and serve as a foundation for future graduate studies.

Since the 1970s, undergraduate early childhood education programmes have been available in Turkey. In the 2015-2016 academic year, there were 87 early childhood education undergraduate programmes (66 day-time and 21 evening education) within 66 universities in Turkey. Furthermore, graduate programmes have been offered in both Graduate Schools of Educational Sciences and Graduate Schools of Social Sciences since 1992. Although there is not adequate information concerning, the first early childhood education graduate study published in Turkey in the literature, Altun, Şendil and Şahin (2011) stated that the first early childhood education graduate programme was established in 1993. However, 
an examination of the National Thesis Database of Turkey reveals graduate studies regarding early childhood education dating back to 1987 and a large number of theses were conducted in a variety of departments. Today, there are 24 graduate education programmes in early childhood education consisting of 19 M.S. and five Ph.D. programmes. In general, in the programmes, the medium of instruction is Turkish, but in Middle East Technical University (METU), instruction is offered in English (Ölçme Seçme ve Yerleştirme Merkezi, 2016). In the 2016 academic year, the total number of staff in early childhood education departments was 755 (70 professors, 64 associate professors, 339 assistant professors, and 282 research assistants) (Yükseköğretim Kurulu, 2017).

Considering the significance of graduate studies regarding early childhood education in Turkey, the current study aims to reveal the descriptive and contextual characteristics and methodological procedures of all online MS theses and PhD dissertations on early children education from 1989 to 2016 regardless of the department in which the study was conducted.

The examination of the international literature shows that studies investigating MS theses and doctoral dissertations reveal research trends dating back to the 1970s (Novak, 1975). The studies were conducted in different fields, such as education, health, and science (Al Kathiri, 2002; Dong, 1998; May \& Holzemer, 1985; Rone, 1998) and various research methods were employed in these studies. Although the studies are prevalent in the education field (curriculum and instruction, blended learning, higher education), to our knowledge, the number of studies investigating early childhood education is limited (Hännikäinen, 2010; Rule, 2011).

In 2010, Hännikäinen examined eight doctoral dissertations published in the last 15 years from educational and other human science departments that described the policy and basic characteristics of early childhood education settings providing services to children aged one to three in Finland. The results of the study indicate that all the dissertations were conducted by female researchers, and the research topics of the dissertations covered specific content areas of early childhood education, such as play, music, and mathematics. In all the dissertations, qualitative and mixed method research designs were applied, and the observation technique was the most commonly used method of data collection. Rule (2011) investigated graduate research regarding both early childhood and basic adult and training in South Africa that was published from 1995 to 2004. According to results of the study, adult and early childhood educations were considered as insignificant fields. There was a lack of doctoral dissertations regarding early childhood education. Although the number of international studies on early childhood education graduate theses is limited, there are available studies in which journal articles regarding early childhood education were examined (Hanson, 1973; Lee, 2012; Zhang, 2015).

In the literature from Turkey, there are a number of journal articles that aimed to investigate graduate theses regarding early childhood education (e.g., Ahi \& Kildan, 2013; Altun et al., 2011; Bertan, Haznedaroğlu, Yurdakök, \& Güçiz, 2009; Can Yaşar \& Aral, 2011; Durukan, Atalay \& Şen, 2015; Kaytez \& Durualp, 2014; Taştepe, Öztürk Serter, Yurdakul, Taygur Altıntaş \& Bütün Ayhan, 2016). Some of these studies discuss early childhood education in general with others focusing on specific aspects, such as drama, play, and inclusion. When the studies are examined, it is seen that all of the articles used document analysis as the data collection method and the data were obtained from the National Theses Database. The sampling methods of the studies varied according to the research questions, and both convenience and criterion-based sampling methods were used by the researchers. In terms of data analysis, descriptive statistics were chosen to present the results of the studies. These studies remain uninfluential because of their limited content and scope. Although the same database was used to obtain graduate theses and similar research methods were applied, the current study aims to conduct a deeper analysis with an inclusive perspective. In the data collection process, no time or department limitation was applied and early childhood education was only used as a keyword. The current study involves a comprehensive analysis with a large sample group and adopts an interdisciplinary understanding, thus, this research is significant in addressing the gap in the literature. 


\section{Significance of the Study}

Universities have several social functions, including scientific research, producing and disseminating scientific information, and making new discoveries. Graduate studies in universities are one of the ways of producing and disseminating scientific information. According to Y1ld1z (2004), both qualitative and quantitative information regarding scientific studies conducted in a specific science area can provide information about the current situation of the field. Hart (1998) lists four reasons that emphasize the necessity of the compilation of scientific studies; (1) to discover which aspects of the field have been studied and which aspects and variable of the field have not yet been investigated, (2) to gain perspective regarding the field, (3) to have comprehensive knowledge about the content of the related field, and (4) to reveal the scientific methods and techniques which are used in the related studies.

The current study provides a comprehensive literature review built upon graduate studies produced by scholars in the field of early childhood education. The results will support the recognition of which subjects are well presented and which are undervalued in graduate studies on early childhood education. Moreover, the findings of this study provide information about current methodological and statistical trends. In addition, the results will provide an opportunity to observe the changes in research trends in early childhood education over the selected time period.

\section{Aim of the Research}

The current study aims to investigate descriptive and contextual characteristics of graduate studies regarding early childhood education to produce a full picture of the field in Turkey. In addition, the study examines the methodological procedures of the theses to reveal the preferred research trends based on the research methods and statistical techniques in these theses. The research questions of the study are;

1. What are the descriptive characteristics (university, institute, department, publication year, language of thesis, and the academic title of the advisor) of MS theses and doctoral dissertations regarding early childhood education in Turkey?

2. What are the contextual characteristics (research topic) of MS theses and doctoral dissertations regarding early childhood education in Turkey?

3. What are the methodological procedures (the sample group, the location where the study took place, research setting of the study, type of research, instruments, statistical analysis, and sampling methods) of the MS theses and doctoral dissertations regarding early childhood education in Turkey?

\section{METHODOLOGY}

\section{Design of the Study}

Qualitative research design was employed to respond to the research questions of the current study. According to Denzin, Norman and Lincon (2000), the qualitative research design is an approach to the world bearing naturalistic and interpretive characteristics. In qualitative studies, researchers attempt to define or interpret the subject with regard to the meanings that people attach to them. In other words, qualitative study is a process which questions and interprets problems regarding community and human problems with specific methods to make interpretations (Creswell, 1998). Moreover, in qualitative studies, researchers attempt to define or interpret the subject with regard to the meanings that people 
attach to them. Yıldırım and Şimşek (2011) define qualitative design as an approach in which observation, interview and document analysis are used as data collection methods. Beliefs and events are revealed in their natural setting in a realistic and holistic way in qualitative studies. In the current qualitative study, document analysis was used as the data collection method. Document analysis is a process in which all written evidence related with the target phenomena analyzed to obtain data. According to Yildırım and Şimşek (2011), document analysis can be used as a solitary data collection method as well as in combination with other methods. In the current study, M.S theses and PhD dissertations approved by graduate schools were used as sources of information in the document analysis process. For the data analysis process, the content analysis method was used in the analysis process of MS theses and PhD dissertations. According to Weber (1990), content analysis is a data analysis method in which data is summarized, classified and interpreted. As the current study aims to examine descriptive characteristics and methodological settings of the graduate theses, the content analysis method was found to be an appropriate method to use for data analysis.

\section{Population and Sampling}

In this study, the population includes all graduate dissertations and theses (collectively referred to as 'theses' in this paper) written on the subject of early childhood education in Turkey. For this reason, working with the whole population of the study is impractical because of time and budget limitations. Hence, the convenience sampling method was applied. Convenience sampling is one of the purposive sampling methods mostly used in qualitative studies (Devers \& Frankel, 2000) and includes individuals who are conveniently accessible for the researcher to use in their studies (Fraenkel, Wallen \& Hyun, 2012). Theses written in both Turkish and English languages were included in the sample. On completion of the data collection process, 1,494 graduate theses were examined, and 1,102 open access theses regarding early childhood education between 1986-2016 were identified as the sample of the study.

\section{Data Collection}

The data collection process of the current study began on 1 September 2016 and was completed on 20 May 2017. The investigation of the theses was conducted by the first author of the article. First, the researcher downloaded the theses having full access permission. Then, the cover pages and the abstracts of the theses were examined. Afterwards, the researcher continued the examination by investigating the summary, introduction, method and the findings sections of the theses to answer the research questions of the study. The total number of theses written on the subject of early childhood education is not known as there are numerous theses written on the subject from a large variety of different departments. Thus, the researcher acquired the theses from two online sources. Firstly, the National Theses Center (CoHE) was searched using the keywords in Turkish "okulöncesi eğitim" (preschool education), "anasınıfı" (nursery class), "erken çocukluk eğitimi" (early childhood education), and "aile katılımı" (parent involvement), and the theses which allowed full text access were identified and downloaded. Secondly, the online databases of 109 state and 76 private university libraries in Turkey were scanned online by the researcher using the same keywords as in the COHE search.

\section{Coding and Categorization}

Fraenkel et al. (2012) defined two different methods of creating categories in content analysis: first is category creation that is conducted prior to the analysis procedure. The researcher creates categories on the basis of the related literature, similar studies, and previous knowledge, theory and experiences. The second method is implemented during the analysis process; thus, the researcher gains more information about the content of the communication and proceeds with the creation of categories. Prasad (2008) stated that content categories are highly related to the literature and the research question; that is, categorization should respond to the query of the research question. For the current study, the researchers devised a categorization based on the related literature and similar MS theses and PhD dissertations. The categories and subcategories of the theses examination processes are presented in Table 1. 
Table 1.

Thesis Examination Categories

\begin{tabular}{ll}
\hline \multicolumn{1}{c}{ Categories } & \multicolumn{1}{c}{ Sub-Categories } \\
& CoHE Thesis Number \\
& Thesis Type \\
& Year of Publication \\
& Name of the University \\
Descriptive characteristics & Name of the Institute \\
& Department \\
& Academic Degree of the Advisor \\
& Language of the Thesis \\
\hline \multirow{5}{*}{ Content Knowledge } & The Sample Group \\
& Content of the Thesis \\
& City/Region of Application \\
& School Setting \\
& School Status \\
\hline & Research Type \\
& Research Design \\
& Scale Type \\
& Data Analysis Technique \\
& Sampling Method \\
& Sample Size \\
\hline
\end{tabular}

\section{Instrumentation}

After defining the categories of content analysis, the unit of analysis was determined by the researchers. In this study, each thesis is defined as the unit of analysis. Subsequently, based on these categories and the unit of analysis, a tentative codebook was prepared by the first author to be used as a coding instrument. This codebook included the descriptive characteristics, the methodological settings, and the publication information of the theses. Then, the codebook and the detailed explanation of the categorization process report were sent to an assistant professor in the early childhood education department to receive the opinion of an expert. After the feedback from the expert, the codebook was reconfigured. The expert's recommendations were mostly related to the vocabulary of the category titles and terminology. Some of the codes were redesigned by searching the related literature. Finally, the thesis examination form was created. Afterwards, a pilot study of the thesis examination form was designed in the light of the expert opinion. The form took its final version at the end of the pilot study.

\section{Validity and Reliability}

Both the validity and reliability of the study was assessed. The validity issue was considered in terms of face validity, external validity and content validity. First, the face validity issue was handled. In the current study, the instrument was developed by the researcher, and the related literature and similar studies were considered during the construction of the instrument. The researcher also received expert opinion from an assistant professor in early childhood education department after preparing the first draft. Based on the expert opinion, the instrument was revised, and the last version of the instrument was constructed via a pilot study. At the end of the pilot study, the instrument was appraised as being valid, having the quality of being able to make the intended measurement. Secondly, the external validity of the instrument was checked. The population of this study includes all graduate theses written on the subject of early childhood education in Turkey. For this reason, it is almost impossible to obtain all the theses; therefore, theses having online full-text access were included in the study. Thirdly, content validity was ensured; two different research assistants who had conducted content analysis studies reviewed the thesis examination form. Lastly, the reliability of the study was ensured. In the current study, both the inter-coder reliability and the test-retest techniques were applied to provide reliable results. The inter-coder reliability was measured using Cohen's Kappa. The Kappa value for the current study was calculated to be .86 , which was a sufficient degree of agreement between the coders. For the test-retest reliability, eight weeks after the first coding was completed, another coder applied the coding procedure once more. 


\section{Data Analysis Procedure}

Descriptive statistics and frequencies were employed for the analysis of the data, and the Statistical Package for Social Science (SPSS 22.0) was used for the data analysis. The findings of the study, the descriptive and methodological characteristics of the graduate theses, are presented in frequency tables and figures.

\section{FINDINGS}

\section{Results Regarding the Descriptive Characteristics}

First, 931 MS theses regarding early childhood education found in the CoHE database were examined according to publication years as shown in Figure 1. The first available MS thesis regarding early childhood education in Turkey was published in 1989, and the highest number of MS theses were published in $2016(\mathrm{n}=100)$.

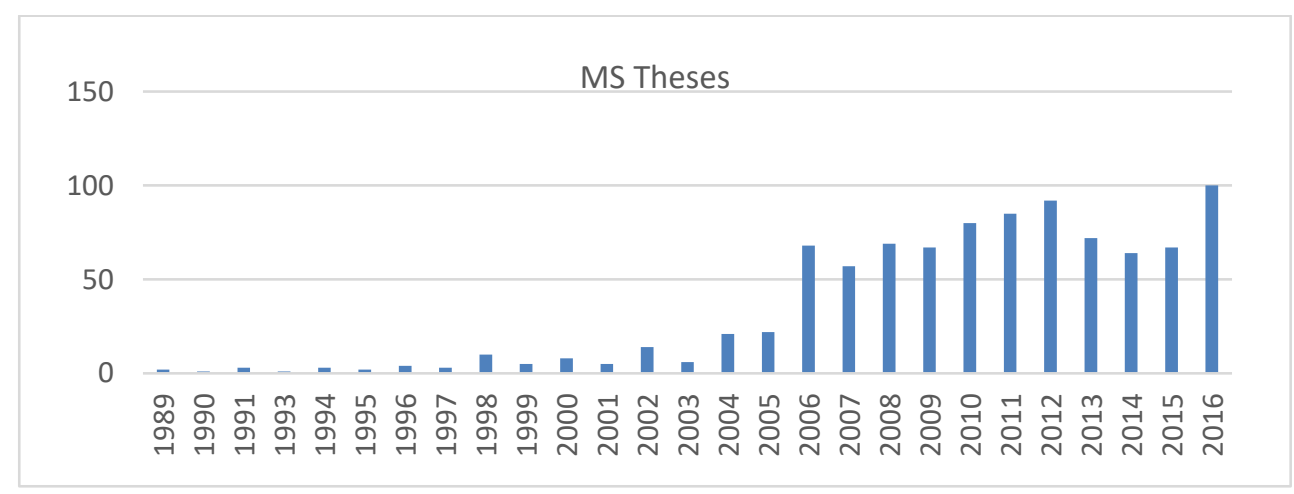

Figure 1. Publication years of MS theses

In addition, $171 \mathrm{PhD}$ dissertations regarding early childhood education were included according to descriptive characteristics. The results related to the publication years of these theses are given in Figure 2 .

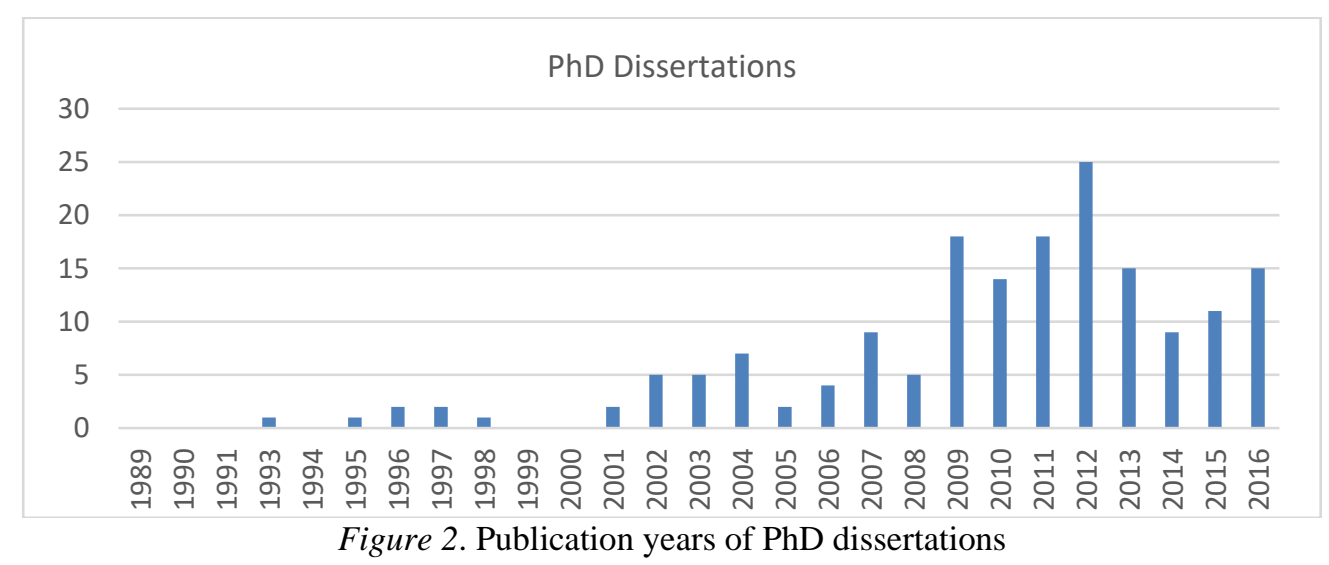

Figure 2 shows that the first available $\mathrm{PhD}$ dissertation regarding early childhood education in Turkey was published in 1993. The results also show that the highest number of $\mathrm{PhD}$ dissertations were published in $2012(\mathrm{n}=25)$. 
Secondly, the names of the universities from which the graduate theses were published were examined by the researcher. The results revealed that of the 78 universities that published M.S thesis, the highest number of MS theses were published by Marmara University $(n=128 ; 13.75 \%)$, followed by Gazi University (9.45\%), Selçuk University (9.13\%), Middle East Technical University (METU) (4.62\%), and Hacettepe University (4.30\%) This distribution of $\mathrm{PhD}$ dissertations across universities show that most of these dissertations ( $\mathrm{n}=41$ ) were published by Gazi University (23.98\%), and Marmara (21.05\%), Ankara (14.62\%), Middle East Technical University (METU) (9.94\%), and Selçuk (8.19\%) universities were the other most productive universities to publish $\mathrm{PhD}$ dissertations. The total number of universities that published the investigated Ph.D dissertations was 20.

Thirdly, the distribution of graduate schools regarding both MS theses and $\mathrm{PhD}$ dissertations was investigated by the researcher. The distribution of graduate schools of graduate theses indicated that 455 MS theses were hosted by the Graduate School of Social Sciences which comprised $48.87 \%$ of the investigated dissertations. This was followed by the Graduate School of Educational Sciences (43.61\%), Graduate School of Natural and Applied Sciences (3.54\%), and Graduate School of Medical Sciences (3.44\%). Unexpectedly, there were also MS theses regarding early childhood education published by the Graduate School of Informatics (0.21\%), Institute of Security Sciences (0.11\%), Graduate School of Fine Arts $(0.11 \%)$, and Institute of Atatürk's Principles and Reforms $(0.11 \%)$. In terms of the PhD dissertations 90 were hosted by the Graduate School of Educational Sciences (52.36\%), followed by the thesis published by the Graduate Schools of Social Sciences (32.16\%), Applied and Natural Sciences $(6.43 \%)$ and Informatics.

Furthermore, the results of the analysis concerning the academic title of the advisors for the MS theses and $\mathrm{PhD}$ dissertations showed that $484 \mathrm{MS}$ theses were supervised by assistant professors $(51.99 \%)$ and 115 of the $\mathrm{PhD}$ dissertations were supervised by professors (67.3\%). As part of this study, the distribution of graduate theses across different departments showed that 383 MS theses regarding early childhood education were hosted by early childhood education departments (41.14\%). Similarly, most of the $\mathrm{PhD}$ dissertations $(\mathrm{n}=47)$ were hosted by early childhood education departments $(27.49 \%)$. Finally, the language of the graduate theses was analyzed. According to the data, most of the graduate theses were written in Turkish (82.05\% of MS theses and $89.47 \%$ of PhD dissertations) with English being the second most preferred language in both MS theses (17.95\%) and $\mathrm{PhD}$ dissertations (10.53\%). The graduate theses written in English were published by both public (Boğaziçi University and METU) and private universities (Bilkent, Yeditepe, Koç and Bahçeşehir universities). These theses were also published from a variety of departments, such as early childhood education, psychology, and business administration.

\section{Results Regarding the Contextual Characteristics}

The research topics of the MS theses and $\mathrm{PhD}$ dissertations were investigated, and the results are given in Table 2.

Table 2.

Research Topics

\begin{tabular}{lcclcc}
\hline MS Theses Research Topic & $\mathrm{f}$ & $\%$ & PhD Dissertations Research Topic & $\mathrm{f}$ & $\%$ \\
\hline Education & 431 & 29.95 & Development & 98 & 32.78 \\
Development & 399 & 27.73 & Education & 92 & 30.77 \\
Teacher/ Administration & 161 & 11.19 & Teaching Methods & 35 & 11.71 \\
Family issues & 123 & 8.55 & Scale dev./adopt. & 24 & 8.03 \\
Teaching Methods & 121 & 8.41 & Family & 21 & 7.02 \\
Health & 56 & 3.89 & Teacher/Administrator & 9 & 3.01 \\
School & 48 & 3.34 & Health & 7 & 2.34 \\
Child Literature & 38 & 2.64 & School & 6 & 2.01 \\
Scale dev./Adopt. & 35 & 2.43 & Media & 5 & 1.67 \\
Media & 23 & 1.60 & Children's Literature & 1 & 0.33 \\
Children's Rights & 4 & 0.28 & Children's Rights & 1 & 0.33 \\
Total & 1439 & 100 & Total & 299 & 100 \\
\hline
\end{tabular}


The data presented in Table 2 shows that education-related issues (29.95\%) were the most frequent research topics that emerged among the analyzed MS theses. In contrast, development-related issues $(\mathrm{n}=98 ; 32.78 \%)$ were the most common research topic in the $\mathrm{PhD}$ dissertations, followed by educational issues $(30.77 \%)$. A detailed list of the sub-dimensions in graduate theses regarding educational issues is presented in Table 3.

Table 3.

Sub-dimensions studied in graduate theses regarding educational issues

\begin{tabular}{lrrlrr}
\hline \multicolumn{1}{c}{ MS Theses Research Topic } & f & \multicolumn{1}{c}{$\%$} & PhD Dissertations Research Topic & f & $\%$ \\
\hline Special Education & 41 & 9.51 & Special Education & 12 & 13.04 \\
School Readiness & 38 & 8.82 & Literacy Skills & 10 & 10.87 \\
Curriculum & 36 & 8.35 & Curriculum & 8 & 8.70 \\
Science Education & 29 & 6.73 & Music Education & 7 & 7.61 \\
Music Education & 28 & 6.50 & School Readiness & 6 & 6.52 \\
Literacy Skills & 26 & 6.03 & Teacher Education & 6 & 6.52 \\
Concept Education & 19 & 4.41 & Education Policies & 4 & 4.35 \\
Art Education & 19 & 4.41 & Science Education & 4 & 4.35 \\
Teacher Education & 18 & 4.18 & Value Education & 3 & 3.26 \\
Language Education & 17 & 3.94 & Environmental Education & 3 & 3.26 \\
Environmental Education & 16 & 3.71 & Concept Education & 3 & 3.26 \\
Educational Technology & 16 & 3.71 & Montessori Approach & 3 & 3.26 \\
V Education & 14 & 3.25 & Vygotsky & 3 & 3.26 \\
Educational Materials & 13 & 3.02 & Mathematic Education & 3 & 3.26 \\
Montessori Approach & 11 & 2.55 & Movement Education & 3 & 3.26 \\
Education Policies & 10 & 2.32 & Education in EU & 2 & 2.17 \\
Mathematic Education & 9 & 2.09 & Turkish Education & 2 & 2.17 \\
Assessment And Evaluation & 9 & 2.09 & Educational Environment & 2 & 2.17 \\
Movement Education & 9 & 2.09 & Constructivism & 1 & 1.09 \\
Turkish Education & 8 & 1.86 & Effects of ECE on school success & 1 & 1.09 \\
Multicultural Education & 7 & 1.62 & Language Education & 1 & 1.09 \\
Constructivism & 6 & 1.39 & Art Education & 1 & 1.09 \\
Effects of ECE on School Success & 6 & 1.39 & Assessment And Evaluation & 1 & 1.09 \\
Other & 26 & 6.03 & Free Time Activities & 1 & 1.09 \\
& & & Gender Education & 1 & 1.09 \\
& & & Educational Technology & 1 & 1.09 \\
Total & 431 & 100 & Total & 92 & 100 \\
\hline & & & &
\end{tabular}

Table 3 shows that special education (9.51\%), school readiness $(8.82 \%)$, and curriculum $(8.35 \%)$ are the main sub-topics commonly studied under the title of education among MS Theses. Special education (13.04\%) and curriculum (8.70\%) were also popular educational research topics in $\mathrm{PhD}$ dissertations. In addition to these sub-dimensions, literacy skills (10.84\%) was among the top-three research topics selected by the PhD authors. The graduate theses also revealed a focus on developmental issues which are listed according to the sub-dimensions in Table 4.

Table 4.

Sub-dimensions studied in graduate theses regarding developmental issues

\begin{tabular}{lrrlrr}
\hline MS Theses Research Topic & \multicolumn{1}{c}{ f } & \multicolumn{1}{c}{$\%$} & PhD Dissertations Research Topic & f & \multicolumn{1}{c}{$\%$} \\
\hline Social-Emotional Dev. & 227 & 56.89 & Social-Emotional Dev. & 45 & 45.92 \\
Cognitive Development & 102 & 25.56 & Cognitive Development & 35 & 35.71 \\
Language Development & 42 & 10.53 & Language Development & 8 & 8.16 \\
Physical Development & 22 & 5.51 & Physical Development & 8 & 8.16 \\
Moral Development & 6 & 1.50 & & & \\
Total & 399 & 100 & Total & 98 & 100 \\
\hline
\end{tabular}

Table 4 shows that social-emotional development (45.92\%) and cognitive development (35.71\%) were the most common developmental areas selected for the PhD dissertations. This topic was also investigated in MS theses on early childhood education, almost equal to educational issues, with social emotional development (56.89\%) being the most preferred research topic in these studies. 


\section{Results of Regarding the Methodological Procedures}

This section gives detailed information about the sample groups, cities in which the studies were conducted, school settings, types of research, research design, instruments, statistical analysis, and sampling methods of both MS theses and PhD dissertations. First, the subject groups of both MS theses and $\mathrm{PhD}$ dissertations were examined to reveal the methodological procedures and the results are presented in Table 5 .

Table 5 .

Subject Groups

\begin{tabular}{lrrlrr}
\hline \multicolumn{1}{c}{ MS Theses Subject group } & \multicolumn{1}{c}{ f } & \multicolumn{1}{c}{$\%$} & PhD Dissertations Subject group & \multicolumn{1}{c}{ f } & \multicolumn{1}{c}{$\%$} \\
\hline Children & 462 & 37.38 & Children & 126 & 53.39 \\
Teacher (in-service- preservice) & 425 & 34.39 & Teachers (in-service- preservice) & 54 & 22.88 \\
Parent (father- mother) & 216 & 17.48 & Parent (father- mother) & 41 & 17.37 \\
School Management & 56 & 4.53 & School Management & 8 & 3.39 \\
Children's Books & 29 & 2.35 & Children's Books & 1 & 0.42 \\
Curricula & 21 & 1.70 & Curricula & 4 & 1.69 \\
School & 16 & 1.29 & School & 0 & 0 \\
Other & 11 & 0.89 & Other & 2 & 0.85 \\
Total & 1236 & 100 & Total & 236 & 100 \\
\hline
\end{tabular}

As indicated in Table 5, children (37.38\%) were the most frequently used sample group in MS theses with a total of 462 theses using students as the subjects. Further analysis showed that three- to six-yearold children $(86.36 \%)$ was the age group mostly preferred by the researchers $(n=399)$. Teachers (34.39\%) composed the second most frequently preferred sample group in MS theses, followed by parents (17.48\%). According to the data presented in Table 5, similar to the MS theses, children (53.39\%) were the mostly frequently used subject group in $\mathrm{PhD}$ dissertations. In $110 \mathrm{PhD}$ theses, groups comprised of three- to six-year-old children were used as the sample group (87.30\%). As in the MS theses, teachers $(22.88 \%)$ and parents $(17.37 \%)$ were the second and third most sample groups preferred by $\mathrm{PhD}$ authors, respectively.

The research areas in which the studies were conducted were analyzed. According to the findings, most MS theses were conducted in the city center and central districts $(\mathrm{n}=845 ; 90.76 \%)$. The results showed that only $0.64 \%$ theses were conducted in rural areas $(n=6)$ with very few of the studies covering both rural and central districts $(1.72 \%)$. Furthermore, there were cross-cultural studies among the analyzed MS theses (2.15\%) which revealed that Germany was the most frequently studied country in these theses $(14.71 \%)$.

Most of the $\mathrm{PhD}$ dissertations were also conducted in the city center and central districts $(89.47 \%)$ together with cross-cultural studies $(4.09 \%)$ and studies covering both rural and central districts $(1.17 \%)$ with no $\mathrm{PhD}$ dissertations being conducted in rural areas. Germany (17.39\%) and the United States of America (17.39\%) were the most frequently studied countries in $\mathrm{PhD}$ dissertations.

In addition to the research area of the study, the Turkish cities in which the studies were conducted were determined revealing that most of the MS theses were conducted in Istanbul (23.31\%), followed by Ankara $(15.15 \%)$ and other cities $(\mathrm{n}<10)(11.71 \%)$. The results also indicate that some of the MS theses covered multiple cities (6.12\%). Of the PhD dissertations, 57 were conducted in Ankara (33.33\%). Lastly, the countries investigated in cross-cultural MS theses and PhD dissertations were Germany $(14.71 \%)$, the United States of America (11.76\%), and European Union countries (11.76\%). The number of $\mathrm{PhD}$ dissertations conducted in the United States of America $(\mathrm{n}=4)$ and Germany $(\mathrm{n}=4)$ was equal. These two countries (17.39\%) were the most frequently studied countries in these $\mathrm{PhD}$ dissertations. The settings of the graduate studies were also analyzed and are shown in Table 6 . 
Table 6.

Research Setting

\begin{tabular}{|c|c|c|c|c|c|}
\hline MS Theses Research Setting & $\mathrm{f}$ & $\%$ & PhD Dissertations Research Setting & $\mathrm{f}$ & $\%$ \\
\hline Preschool & 633 & 48.62 & Preschool & 99 & 50.51 \\
\hline Preschool Class & 322 & 24.73 & Preschool Class & 43 & 21.94 \\
\hline Crèshes/ Nursery School & 83 & 6.37 & Crèshes/ Nursery School & 9 & 4.59 \\
\hline Primary School & 75 & 5.76 & Primary School & 9 & 4.59 \\
\hline High School & 27 & 2.07 & High School & & \\
\hline College & 42 & 3.23 & College & 6 & 3.06 \\
\hline $\begin{array}{l}\text { Counselling Research/Rehabilitation } \\
\text { Center }\end{array}$ & 18 & 1.38 & $\begin{array}{l}\text { Counselling Research/Rehabilitation } \\
\text { Center }\end{array}$ & 7 & 3.57 \\
\hline Other & 20 & 1.54 & Other & 7 & 3.57 \\
\hline Not Applicable & 49 & 3.76 & Not Applicable & 9 & 4.59 \\
\hline Not Specified & 33 & 2.53 & Not Specified & 7 & 3.57 \\
\hline Total & 1302 & 100 & Total & 196 & 100 \\
\hline
\end{tabular}

Table 6 indicates that preschools catering for three- to six-year-old children $(48.62 \%)$ were the most frequently used research setting in MS theses. Preschool classes functioning independently or within a primary school (24.73\%) were the second most frequently used research setting in MS theses. Thirdly, crèches and nursery schools $(6.37 \%)$ were also used as research settings. As indicated in Table 6, preschools $(50.51 \%)$ were the most frequently used research settings in $\mathrm{PhD}$ dissertations, followed by preschool classes $(21.94 \%)$, primary schools $(4.59 \%)$, and crèches $(4.59 \%)$.

Next, the statuses of the research setting in graduate theses were investigated and the findings revealed that both MS (53.9 \%) and $\mathrm{PhD}$. (61.4\%) authors mostly preferred public research settings. Private/foundation settings were the second choice in both MS theses (11.1\%) and PhD dissertations (5.3\%). The research methods of the examined graduate theses findings are presented in Table 7.

Table 7.

Research Type

\begin{tabular}{lcrlrr}
\hline \multicolumn{1}{c}{ MS Theses Research Type } & $\mathrm{f}$ & $\%$ & PhD Dissertations Research Type & $\mathrm{f}$ & $\%$ \\
\hline Quantitative & 638 & 68.53 & Quantitative & 102 & 59.65 \\
Qualitative & 166 & 17.83 & Qualitative & 29 & 16.29 \\
Mixed Method & 127 & 13.64 & Mixed Method & 40 & 23.39 \\
Total & 931 & 100 & Total & 171 & 100 \\
\hline
\end{tabular}

As can be seen in Table 7, in most of the MS theses (68.53\%), a quantitative research method was employed, followed by qualitative research methods (17.83\%). Mixed method (13.64\%) studies were found to be the least preferred type of approach. In most of the $\mathrm{PhD}$ dissertations, the researchers employed quantitative (59.65\%) research methods and in contrast to the MS theses for $\mathrm{PhD}$ researchers, the mixed method $(23.39 \%)$ was the second popular research type wit qualitative research being the least preferred method of research. In addition to the type of research, research designs of the graduate studies were analyzed by the researchers and the results are provided in Table 8.

Table 8.

Research Desig

\begin{tabular}{lrrlrr}
\hline MS Theses Research Design & \multicolumn{1}{c}{ f } & \multicolumn{1}{c}{$\%$} & PhD Dissertations Research Design & f & $\%$ \\
\hline Survey & 551 & 56.45 & Experimental & 86 & 43.65 \\
Experimental & 189 & 19.36 & Survey & 52 & 26.40 \\
*Interview & 43 & 4.41 & Case study & 12 & 6.09 \\
Case study & 36 & 3.69 & Phenomenological & 7 & 3.55 \\
Descriptive & 33 & 3.38 & *Interview & 5 & 2.54 \\
Not specified & 29 & 2.97 & Single subject & 5 & 2.54 \\
Content Analysis & 15 & 1.54 & Literature Review & 4 & 2.03 \\
Phenomenological & 13 & 1.33 & Descriptive & 4 & 2.03 \\
Correlational & 10 & 1.02 & Other & 22 & 11.17 \\
Literature Review & 6 & 0.61 & & & \\
Action research & 5 & 0.51 & & & \\
Field Research & 5 & 0.51 & & & \\
Document Analysis & 6 & 0.61 & & & \\
Causal Comparative & 4 & 0.41 & & 197 & 100 \\
Other & 31 & 3.18 & & & \\
Total & 976 & 100 & Total & & \\
\hline
\end{tabular}

*Researchers define their research design as interview. 
It is apparent from Table 8 that the survey (56.45\%) was the most preferred research design MS theses. The second favorite research design was experimental and third was interviews. Research designs found less than four times in the dissertations are indicated as 'other' in the table.

The distribution of the preference for research designs in $\mathrm{PhD}$ dissertations are shown in Table 8 with the most favored being experimental design (43.65\%). In contrast to the MS theses, survey design (26.40\%) was the second preferred design and case study (6.09\%) was in third place in the $\mathrm{PhD}$ dissertations.

In addition to research design, the data collection tools used in graduate studies were analyzed, and the results are given in Table 9.

Table 9.

Data Collection Tools

\begin{tabular}{lrrlrc}
\hline MS Theses Data collection tool & \multicolumn{1}{c}{ f } & \multicolumn{1}{c}{$\%$} & PhD Dissertations Data collection tool & f & $\%$ \\
\hline Questionnaire & 531 & 37.00 & Questionnaire & 78 & 24.84 \\
Achievement/Apt. Test & 17 & 15.12 & Ach./Aptitude Test & 68 & 21.66 \\
Interview & 187 & 13.03 & Interview & 43 & 13.69 \\
Document Analysis & 106 & 7.39 & Performance Dev./Test & 34 & 10.83 \\
Performance/Dev. Test & 103 & 7.18 & Observation & 33 & 10.51 \\
Attitude Scale & 85 & 5.92 & Document Analysis & 18 & 5.73 \\
Observation Form & 73 & 5.09 & Rating Scale & 17 & 5.41 \\
Rating Scale & 64 & 4.46 & Attitude Scale & 11 & 3.50 \\
Checklist & 30 & 2.09 & Checklist & 10 & 3.18 \\
Personality Test & 21 & 1.46 & Socio-Metric Devices & 2 & 0.64 \\
Audio-Visual Materials & 12 & 0.84 & & & \\
Socio-Metric Devices & 4 & 0.28 & & & \\
Other & 2 & 0.14 & & 314 & 100 \\
Total & 1435 & 100 & Total & & \\
\hline
\end{tabular}

Table 9 shows that questionnaires $(37.00 \%)$ were preferred mostly by the researchers as the data collection tool in MS theses, followed by achievement/aptitude tests (15.12\%) and interviews (13.03\%). As can also be observed in Table 9, as in the MS theses questionnaires (24.84\%) were the most frequently preferred data collection method in $\mathrm{PhD}$ dissertations, followed by achievement/aptitude tests (21.66\%), and interviews (13.69\%).

The statistical tests used in the graduate theses were also identified and the distribution of the statistical tests are presented as nonparametric, univariate, multivariate and bivariate tests in Table 10.

Table 10.

Statistical Tests

\begin{tabular}{lcclcl}
\hline MS Theses Statistical test & $\mathrm{f}$ & \multicolumn{1}{c}{$\%$} & PhD Dissertations Statistical test & $\mathrm{f}$ & $\%$ \\
\hline Non-Parametric & 461 & 23.77 & Non-Parametric & 116 & 29.86 \\
Bivariate & 161 & 8.30 & Bivariate & 28 & 7.19 \\
Univariate & 891 & 45.95 & Univariate & 156 & 40.10 \\
Multivariate & 426 & 21.97 & Multivariate & 89 & 22.87 \\
Total & 1939 & 100 & Total & 389 & 100 \\
\hline
\end{tabular}

As indicated in Table 10, univariate tests $(45.95 \%)$ were the most preferred statistical test in MS theses. with nonparametric tests $(23.27 \%)$ being second and multivariate tests $(21.97 \%)$ being third. In the findings regarding the distribution of data analysis methods employed in $\mathrm{PhD}$ dissertations are similar to those reported for the MS theses (Table 10). Univariate (40.10\%) was the most frequently used test in $\mathrm{PhD}$ dissertations. followed by nonparametric tests $(29.86 \%)$; however, the third favorite statistical test was multivariate (22.87). Another variable that was examined was the sampling method used in the graduate theses, and the results were presented in Table 11. 
Table 11.

Sampling Methods

\begin{tabular}{lrrlrr}
\hline MS Theses Sampling Method & \multicolumn{1}{c}{ f } & \multicolumn{1}{c}{$\%$} & PhD Dissertations Sampling Method & f & $\%$ \\
\hline Purposive & 223 & 24 & Purposive & 65 & 38.0 \\
Simple Random & 285 & 30.6 & Simple Random & 49 & 28.7 \\
Convenience & 220 & 23.6 & Convenience & 32 & 18.7 \\
Cluster Random & 50 & 5.4 & Cluster Random & 8 & 4.7 \\
Stratified Random & 30 & 3.2 & Stratified Random & 6 & 3.5 \\
Population & 36 & 3.6 & Population & 3 & 1.8 \\
Not Specified & 59 & 6.3 & Not Specified & 4 & 2.3 \\
Not Applicable & 26 & 2.8 & Not Applicable & 4 & 2.3 \\
Total & 931 & 100 & Total & 171 & 100 \\
\hline
\end{tabular}

From the data in Table 11, it is apparent that in most of the MS theses, the simple random sampling method (30.6\%) was used to define the sample of the studies followed by purposive $(24.00 \%)$ and convenience (23.6\%) sampling methods. As indicated in Table 11, contrary to MS theses, purposive sampling (38.00\%) was revealed to be the most preferred sampling method among the $\mathrm{PhD}$ dissertations, while simple random sampling $(28.7 \%)$ was the second most preferred method of sampling.

Lastly, the sample sizes of the graduate theses were investigated. The findings showed that in most of the MS theses, the sample groups included more than 200 subjects (35.3\%). However, in $25.6 \%$ of the MS theses, the sample groups had less than 50 subjects. In PhD dissertations, most of the studies had sample groups smaller than 50 subjects (32.7\%). Secondly, PhD researchers had smaller groups - who preferred 50-100 subjects. Further analysis revealed that the average sample size was 192.08 for the MS theses and 184.58 for the $\mathrm{PhD}$ dissertations.

\section{DISCUSSION and CONCLUSION}

\section{Descriptive Characteristics of the Graduate Theses}

As can be seen from the findings of the current study, graduate studies regarding early childhood education were not only published in early childhood education departments. In Turkey, MS theses regarding early childhood education began to be published in 1989 in child health and education departments. The first $\mathrm{PhD}$ dissertation in this area was published in 1993 in the architecture department. The first graduate early childhood education programme was opened in 1993, with the first MS thesis produced from that education department being published in 1996. Then, the first $\mathrm{PhD}$ dissertation was published in 2001 by a student from the same department.

In 2016, 1,102 early childhood education graduate these were published, of which $931(84.37 \%)$ were MS theses and 171 (15.52\%) were PhD dissertations. Previous studies conducted by McLean Davies, Anderson, Deans, Dinham, Griffin, Kameniar, Page, Reid, Rickards, Taylor, and Tyler (2012) and Göktaş, Hasançebi, Varışoğlu, Akçay, Bayrak, Baran, \& Sözbilir (2012) suggested that master programmes were more common and available for graduate students in comparison with doctoral programmes. These programmes also have higher student numbers and simpler requirements than the doctoral programmes. Therefore, it is an expected result that there are more MS theses on early childhood education than $\mathrm{PhD}$ dissertations.

When the fluctuation in the number of graduate theses was examined, there were short-term increases in the number of MS theses produced from 1998 to 2002. A further increase in the number of MS theses was determined between 2004 and 2012. In 2013, the number of available MS decreased but in 2016, it reached its highest level $(n=100)$. Similarly, PhD dissertations gradually increased until 2012; however, since then, there has been a decrease in the number of available $\mathrm{PhD}$ dissertations. These findings agree 
with the study of Ahi and Kildan (2013), which showed that the number of theses steadily increased from 1998 to 2006 but with an irregular distribution. A possible reason for this result may be due to a researcher wanting to restrict the availability of their thesis until they publish the findings of their study. In another study, Altun et al. (2011) stated that this decrease might have been caused by a delay in the registration process and the uploading of new theses to the online database.

The examination of the universities that produced the graduate theses showed that some led the field, with Marmara and Gazi being the most productive universities, followed by Ankara University, METU and SelçukUniversity. Although most of the graduate theses were written by students attending these particular universities, the result of the analysis showed that 128 universities had published MS theses, and 41 universities had published $\mathrm{PhD}$ dissertations, regarding early childhood education under various departments. It is possible to make this interpratetion because although the number of early childhood education graduate programmes is limited, the importance of early childhood education is appreciated by other departments and is mentioned in the graduate theses written in these departments. Another possible explanation for this result is that Gazi University and Marmara University have more MS and $\mathrm{PhD}$ programmes than other universities and these programmes were opened earlier than in other universities (Gazi University Graduate School of Education Science, 2016).

Moreover, it has become clear that graduate theses regarding early childhood education emanated from several graduate schools. While the majority of the investigated MS theses were published in the Graduate School of Social Sciences, a considerable number of PhD dissertations were published in the Graduate School of Educational Sciences. These findings further support those determined by Durukan et al. (2015). There are several possible explanations for this result. First, until recently, early childhood education graduate programmes have offered within the purview of the Graduate School of Social Sciences, and furthermore Graduate Schools of Educational Sciences have only recently become prevalent. Another explanation for this result may be a rise in the popularity of interdisciplinary studies. The interests of different departments, which offer the opportunity to study education within different graduate schools, resulted in graduate studies regarding early childhood education being published under various graduate schools. In addition, one unexpected finding suggests that MS theses regarding early childhood education were also published in the Graduate School of Security Science and Graduate School of Ataturk's Principles and Reforms.

The results of the current study indicated that early childhood education, and child development and education departments were the most productive in terms of graduate theses regarding early childhood education. However, the majority of the graduate theses were produced within departments of early childhood education. In contrast, the findings of previous studies also showed that the number of theses concerning child development and education was higher than early childhood education graduate theses. One of the possible explanations for this result is that child development and education departments have been providing undergraduate, MS and $\mathrm{PhD}$ programmes since the 1970s, while the establishment of early childhood education programmes only began in 1998 (Haktanır, Dağlığlu, \& Güler, 2010). Nevertheless, this may explain why today, early childhood education departments are the main sources of early childhood education-related graduate theses.

In contrast, in the study by Altun et al. (2011), early childhood education was also mentioned in a variety of departments. One surprising finding of the current study was that sample studies were found that were related with early childhood education, which were published under a variety of departments, including manufacturing and marketing, occupational health and safety, veterinary medicine, and finance and business administration. Based on these findings, it can be determined that early childhood education is an interdisciplinary area that draws interest from different departments. Moreover, these studies may offer the opportunity to consider studies concerning early childhood education from different perspectives.

Comparing the academic titles of the advisors of MS theses and PhD dissertations regarding early childhood education, different results were obtained. While more than half of the MS theses were 
supervised by assistant professors, the majority of $\mathrm{PhD}$ dissertations were supervised by professors. According to Yavuz (2016), this is an expected result since there are more MS students than $\mathrm{PhD}$ students, and there are a greater number of academic staff holding the position of assistant professor. Conversely, Polat (2013) suggested that PhD students prefer to be supervised by professors. Another reasonable explanation for this finding might be that supervising a $\mathrm{PhD}$ dissertation may require more academic skills and experience. Moreover, according to the current Graduate Education Regulations in Turkey, an assistant professor should first supervise an MS thesis before supervising a student writing a $\mathrm{PhD}$ dissertation (The Higher Education Law, 1981).

\section{Contextual Knowledge of Graduate Theses}

The findings regarding topics in graduate theses showed that those related to education development and teacher/administrator were the most common research topics in MS theses, on early childhood education. As Ahi and K1ldan's (2013) study stated, education was the most frequent research topic in early childhood education graduate theses. Special education $(9.51 \%)$, school readiness $(8.82 \%)$, and curriculum $(8.35 \%)$ were the subjects mostly focused upon among education-related research topics. The MS theses regarding developmental issues mostly focused on social-emotional (56.89\%), cognitive $(25.56 \%)$ and language $(10.53 \%)$ development. Social skills, including adaptation, self-confidence, selfregulation, and self-efficacy $(29.96 \%)$ were the most frequently studied research issues among socialemotional development topics.

In $\mathrm{PhD}$ dissertations, researchers mostly concentrated on development (32.78\%), education (30.77\%) and teaching methods $(11.71 \%)$ issues. As in MS theses, social-emotional development, especially social skills, were the most studied areas in PhD dissertations, regarding early childhood education. This finding is in agreement with those of Taştepe et al. (2016), which showed that graduate theses frequently focused on social development. On the other hand, special education (13.04\%) and literacy skills (10.87\%) were the most frequently studied fields among educational research topics in $\mathrm{PhD}$ dissertations. Moreover, Altun and Sar1 (2018) found that the number of studies which focused on literacy skills, such as the letter-sound relation, phonological awareness and spelling was increasing each year. This result may be due to the outcome of recent research which claims the critical importance of the early years in language development (Campbell et. al. 2002).

\section{Methodological Procedures of Graduate Theses}

The third research question of the current study consists of the methodological procedures (i.e. the study group, the location in which the study took place, the school hosting the study, the type of research, the instruments used, the statistical and sampling methods, etc.) of the graduate theses regarding early childhood education in Turkey. The results of the current study indicate that children/students are the most frequently studied subject group for both MS theses and $\mathrm{PhD}$ dissertations, which was not an unexpected finding. However, when the age groups of the samples were examined, they showed that almost all graduate theses focused on three- to six-year-old children (86.36\% of MS theses, $87.30 \%$ $\mathrm{PhD}$ dissertations). Zero to three-year-old children were the most under-studied age group in the graduate theses $(0.87 \%$ of MS theses and 0.79 of $\mathrm{PhD}$ dissertations). This finding corroborates the research of Ahi and Kildan (2013), who suggested that most of studies and theses covering early childhood education focused on children between the ages of three and six. This may be explained by the fact that contrary to international agreements, and, according to the Turkish Ministry of National Education, early childhood education covers the education of children in this age group which constitutes the highest population in a pre-school setting. For this reason, researchers tend to include three- to six-year-old children in their studies.

The second most frequently used sample group in graduate studies is that of teachers, including inservice, preservice and field teachers. Although elementary school teachers were included in sample groups of MS theses (6.59\%), no PhD dissertations were found to have focused on elementary school teachers. In-service teachers were the most frequent sample group among the graduate theses that 
focused on teachers (82.12\% of MS theses, $88.89 \%$ of $\mathrm{PhD}$ dissertation). There are several possible explanations for this result. Firstly, in Turkey, most graduate students are employed as research assistants or teachers. Therefore teachers and students are the most convenient research group for these studies. Secondly, as most of the graduate theses were published in early childhood education departments, researchers were mostly interested in teachers and students as they are the principle actors in early childhood education.

In most of the graduate studies that focused on parents, only mothers or both parents were the target groups. The studies which focused only on fathers ( $\mathrm{n}=7$ for MS these, $\mathrm{n}=1$ for $\mathrm{PhD}$ dissertations) were significantly lower than those covering only the mothers and/or both parents. This finding is also in accordance with earlier studies (Altun et al., 2011). However, studies also included grandparents, academicians, inspectors, visual materials, and adjunct staff as sample groups in graduate theses.

Further analysis showed that teacher and student sample groups were preferred mostly by early childhood education researchers. In other respects, parents and children sample groups were mostly chosen as the focus by child development researchers.

What is surprising is that although family-related research topics had been studied more frequently in early years, this focus lost its significance in later years. In 2016, language development was the most popular research topic among published graduate theses. A possible explanation for this may be the results of current scientific research on language development which suggests that successful early language development is a vital part of later achievements.

The current study also revealed the characteristics of research settings in which these studies were conducted indicating that nearly all graduate theses were conducted in the city center or central districts (90.76\% of MS theses and $89.47 \%$ of $\mathrm{PhD}$ dissertations). While 22 of the MS theses (2.38\%) included research settings in rural districts or rural and central districts, only two $\mathrm{PhD}$ dissertations (1.17\%) were undertaken in rural districts. It seems possible that this result is due to the low schooling rate in rural areas. Graduate studies conducted in cities were mostly found to have been in located in metropolitan conurbations, such as Ankara, İstanbul, Konya, Eskişehir, and İzmir. There are several reasons to explain this finding. First, the universities in which most of these studies were conducted also located in these cities. Second, the density of the population in these cities provided easily available sample groups. Another important finding was that there were cross-cultural studies in both MS theses and $\mathrm{PhD}$ dissertations. Germany was the most frequently studied country in both M.S theses $(14.71 \%)$ and PhD dissertations (17.39\%). Another regularly studied country in graduate theses was the United States of America (11.76\% of MS theses and $17.39 \%$ of $\mathrm{PhD}$ dissertations). European Union countries were also investigated in graduate theses. A possible explanation for these findings might be that international relations regarding graduate studies allow for easier access to data and analysis. The labor migration from Turkey to Germany and Turkey's ongoing application for membership of the European Union could have had an effect on the choice of countries studied in the graduate theses.

In contrast to the findings of previous studies, not surprisingly, pre-school education is again the most preferred level investigated in graduate theses. Also, since kindergartens cater to three- to six-year-old children in Turkey, they are the most frequent research setting in both MS theses and PhD dissertations and provide easy opportunities for data collection. The study also found that in both MS and $\mathrm{PhD}$ dissertations, researchers mostly preferred public-school settings. This result agrees with the findings of other studies, which reported that most research focused on public schools (Dungan \& Pryzwansky, 1988). According to Al Kathiri (2002), private education institutions did not allow graduate students to conduct studies in their schools, as some parents would not approve of the study. Therefore, business concerns might be a possible reason for this finding.

As indicated in the current study, most of the graduate theses employed quantitative research methods. In the MS theses, qualitative studies were less frequent than quantitative, while mixed method studies were the least frequent. Moreover, mixed method studies were the second most frequent studies among 
$\mathrm{PhD}$ dissertations. The number of qualitative studies was higher in $\mathrm{PhD}$ dissertations because they require more in-depth research. Contrary to this finding, according to Hännikäinen (2010), almost all $\mathrm{PhD}$ dissertations regarding early childhood education in Finland used qualitative methods or at least combined both qualitative and quantitative methods to collect data. Also, in his study, Rule (2011) found that most of the early childhood education graduate theses were qualitative in style. On the other hand, the conclusions from the work of Ahi and Kildan (2013) and Durukan et al. (2015) suggest that in early childhood education theses, quantitative research methods are more frequently used than other methods. It is difficult to explain this result, but it might be related to the cultural differences of the researchers.

According to the findings of the current study, although the most frequent research design varied according to the type of theses, survey and experimental designs were the most popular research settings used in both MS theses and doctoral dissertations. In the former group, survey was dominant research design, followed by experimental design. According to Erdoğmuş (2009), in survey studies, researchers obtained the opinions and attitudes of learners, teachers, parents and administrators in regard to computer use in education and different variables. In accordance with this idea, it might be possible that the researchers of early childhood education graduate theses, who provided the surveys, intended to study and analyze the opinions, beliefs and attitudes of sample groups. On the other hand, in $\mathrm{PhD}$ dissertations, researchers generally employed an experimental research design. This result may be explained by the fact that in $\mathrm{PhD}$ dissertations, researchers aimed to reveal the effects of different variables on child development. For this reason, experimental designs, which provided the ability to check cause and relationships among variables (Frankel \& Wallen, 1993), were preferred by the researchers.

Another important finding of the study is that questionnaires, achievement/aptitude tests and interviews were the most common data collection methods used in the graduate theses. Also, the study found that most of the time, researchers combined more than one data collection method. This result may be explained by survey research design, in which researchers use questionnaires to collect data. As Fowler stated in 2002, administering questionnaires is one of the most common data collection methods used in survey design studies. Another explanation for this finding can be that the results of the questionnaires are easily analyzed by the researchers. Aptitude and achievement tests were used to measure the sample group's intelligence and skills or to test knowledge of an individual in a particular area (Frankel \& Wallen, 1993). Researchers, especially in experimental design studies, may have used this data collection method to measure the effect of treatment on the intended variable.

The third most common data collection method in graduate theses utilized interview protocols, which aim to reveal what was on the subject's mind, what the subject thought or how the subject felt about a particular issue (Frankel \& Wallen, 1993). Considering the purpose of the interview method, it may be claimed that researchers preferred this data collection method in order to discover the thoughts and feelings of the subjects. Also, as the most common sample group in the graduate theses was three- to six-year-old children, questionnaires are sometimes unable to ascertain the ideas of young children due to their possible, limited understanding of the questions.

In contrast to the findings of the current study, Rule (2011) found that observation, rather than interviewing, was the most common method in the studies conducted in day care centers in Finland. Both participant and non-participant observation procedures were used as data collection methods. However, researchers combined observation methods with other data collection approaches; thus, this finding confirms the association between graduate theses conducted in Turkey and Finland. A possible explanation for the underuse of observation techniques in Turkey might be time limitations. As the observation method is a time-consuming technique, researchers use more practicable techniques like questionnaires. Also, in Turkey, it is very difficult to receive permission from the school administration to be able to observe sample subjects.

When the statistical test used in the data analysis process of MS theses was analyzed, it was found that researchers mostly used univariate statistical tests, especially the t-test and ANOVA, which are generally 
used for comparing group means. Multivariate statistical tests which are used to investigate the degree of relations among variables were the third most employed method among the MS theses. According to these results, researchers should increase the variety of statistical tests used in their studies to develop clearer interpretations among variables.

In addition, SPSS, which allows easy application of the t-test and ANOVA analyses, was the most common package used in graduate theses. A possible explanation for the researchers using this programme is that it is easy to use and free of charge.

Moreover, the study revealed that sampling methods used in the graduate theses vary in accordance with the research designs. Simple random sampling was the most common method used in MS theses. Al Kathiri (2002) found that using a population was the most common sampling method in curriculum and instruction MS theses. It is difficult to explain this result but perhaps due to their findings, which mostly used survey studies, researchers engaged in MS studies preferred to apply a simple random method to define sample groups. Also, as most common sample groups were children, teachers and parents in MS theses, simple random sampling can be considered as the appropriate method to define a sample group in such large populations. Not surprisingly, the sample group of the MS theses was generally larger than 200 members, which indicates that the generalizability of the results was higher.

In most of the PhD dissertations, the researcher used purposive sampling, which is the most common sampling method implemented in experimental research studies. Erdoğmuş (2009) also defended this finding in her study by suggesting that purposive sampling was one of the most common sampling methods used in instruction technology $\mathrm{PhD}$ dissertations. There are several explanations for this result. Firstly, researchers do not consider the representativeness of the sample group in purposive sampling. Secondly, experimental design research was the most common research design in $\mathrm{PhD}$ dissertations; therefore, the result might be related with the research designs. Also, purposive sampling may have reduced time and financial expenditure. It seems that researchers preferred purposive sampling, in particular when faced with a limited time to complete their studies. In accordance with sampling method, the sample groups of $\mathrm{PhD}$ dissertations consisted of less than 50 members.

\section{Suggestions}

The main finding of the current study is that early childhood education has been the topic of graduate theses since 1989 prepared by students in several departments. Some specific universities, located in metropolitan areas, having qualified and experienced academic staff, led the field by producing the majority of graduate theses; thus, there was an uneven distribution of graduate theses across the universities in Turkey. To prevent this inequality, the quality and quantity of academic staff in other universities should be improved.

The sample groups that were selected in both MS theses and PhD dissertations had similar characteristics. Children were at the heart of the early childhood education field, and they were the most popular subject to be observed in graduate theses. However, some age groups, including zero- to threeyear-old children and six + ages were undervalued in graduate studies. To increase the studies to cover zero- to eight-year old children, both MS and PhD students should be encouraged to expand their sample pools. On the other hand, teachers were the second most popular group in graduate theses, but most focused on in-service teachers. The training of pre-service teachers has as much value as in-service training and the number of studies regarding prospective teachers should be increased. Also, fathers, academicians, ancillary professionals, and educational materials should be considered as sample groups in graduate theses.

In Turkey, the government aims to increase the attendance rate within preschool level education across the country. However, the results showed that apart from Istanbul, there is a big gap in the preschool enrolment rates in the western and eastern parts of the country (Ministry of National Education, 2014). According to Ağırdağ, Yazıcı and Sierens (2015), one promising strategy to improve schooling rates at 
preschool level is to increase quality of preschool education in less developed provinces and improve the accessibility of preschool education for children from low socio-economic status families. Therefore, to increase the quality and accessibility of preschool education, less developed provinces should be considered. In the examination of the research settings of the graduate theses, most of the studies were conducted in city centers; thus, rural areas and less developed provinces were ignored within graduate studies. Increasing the number of graduate studies conducted in rural districts would offer opportunities to cultivate the quality of and access to early childhood education in these areas.

While educational and developmental issues have been frequently studied in graduate theses, some educational and developmental topics are mostly overlooked; for example, peace education, democracy education and gender education. On the other hand, physical development and moral development are understudied topics among developmental studies. Furthermore, some topics regarding interdisciplinary studies, such as children's rights, child abuse and media should also be considered in graduate theses.

According to the findings, the number of quantitative studies was significantly higher than qualitative studies. Research employing qualitative research methods can provide in-depth information about the nature of the studied materials. For this reason, the number of qualitative studies should be increased in order to attain more in-depth information. Furthermore, using different types of research designs and data collection methods can promote the development different perspectives in regard to the field.

This study examined graduate studies regarding early childhood education in Turkey and all online, open access graduate theses written up to 2017 were included in the study. In later studies, journal articles regarding early childhood education in Turkey can be identified according to descriptive characteristics, contextual knowledge, and methodological procedures.

\section{Acknowledgement}

This study was derived from master's thesis entitled "A Content analysis of graduate theses concerning early childhood education in Turkey", completed at Graduate School of Social Sciences of Middle East Technical University in 2017.

\section{REFERENCES}

Ağırdağ, O., Yazıcı, Z., \& Sierens, S. (2015). Trends in pre-school enrolment in Turkey: Unequal access and differential consequences. Comparative Education, 537-554. https://doi.org/10.1080/03050068.2015.1081796

Ahi, B., \& Kildan, A. O. (2013). An Overview of postgraduate thesis within the field of pre-school education in Turkey (2002-2011). Mehmet Akif Ersoy University Journal of Faculty of Education, 1(27), 23-46. Retrieved from http://dergipark.gov.tr/maeuefd/issue/19400/206141

Al Kathiri, S. N. (2002). The Characteristics of master's theses conducted in the department of curriculum \& teaching methods from 1983 through 2002 at King Saud University, Saudi Arabia (Unpublished doctoral dissertation). University of Arkansas, Fayetteville.

Altun, D., \& Sarı, B. (2018). A Decade of early literacy research trends in Turkey: A Thematic review. Journal of Education and Future, (13), 13-32. Retrieved from http://dergipark.gov.tr/jef/issue/35229/390811

Altun, D., Şendil, Ç. Ö., \& Sahin, İ. T. (2011). Investigating the national dissertation and thesis database in the field of early childhood education in Turkey. Procedia-Social and Behavioral Sciences, 12, 483-492. https://doi.org/10.1016/j.sbspro.2011.02.060

Bertan, M., Haznedaroğlu, D., Yurdakök, K., \& Güçiz, B. D. (2009). Studies on early childhood development in Turkey (2000-2007). Turkish Journal of Pediatric Disease, 52(1), 1-8.

Brandt, R. S. (Eds.). (2000). Education in a New Era. In Association for Supervision and Curriculum Development, 2000 ASCD Yearbook (21-46). Alexandria, VA: Association for Supervision and Curriculum Development. 
Can Yaşar, M., \& Aral, N. (2011). An Overview of postgraduate theses within the field of drama at early childhood education in Turkey. Mehmet Akif Ersoy University Journal of Education Faculty, 1(22), 70-90. Retrieved from http://dergipark.gov.tr/download/article-file/181331

Campbell, F. A., Ramey, C. T., Pungello, E., Sparling, J., \& Miller-Johnson, S. (2002). Early childhood education: Young adult outcomes from the Abecedarian Project. Applied Developmental Science, 6(1), 42-57. https://doi.org/10.1207/S1532480XADS0601_05

Cresswell, J.W. (1998). Research Design: Qualitative, Quantitative and Mixed Method Approaches. (2 ${ }^{\text {nd }}$ Ed.) London: Sage Publications.

Denzin, Norman K. and Lincoln, Yvonne S. (2000). Handbook of qualitative research ( $\left.2^{\text {nd }} \mathrm{Ed}\right)$. London: Sage Publication.

Devers, K. J., \& Frankel, R. M. (2000). Study design in qualitative research-2: Sampling and data collection strategies. Education for Health, 13(2), 263. http://doi.org/10.1080/13576280050074543

Dong, Y. R. (1998). Non-native graduate students' thesis/dissertation writing in science: Self-reports by students and their advisors from two US institutions. English for Specific Purposes, 17(4), 369-390. https://doi.org/10.1016/S0889-4906(97)00054-9

Dungan, C. F., \& Pryzwansky, W. B. (1988). Consultation research: Trends in doctoral dissertations 1978-1985. Journal of School Psychology, 26(2), 107-119. Retrieved from https://eric.ed.gov/?id=EJ377279

Durukan, H., Atalay, Y., \& Şen, N. (2015). Investigate of the postgraduate thesis on the field of pre-school education in Turkey between 2000-2014 years. Dicle University Journal of Ziya Gökalp Faculty of Education, 26, 62-77. https://doi.org/10.14582/DUZGEF.626

Ebel, J. E. (n.d.). FAQ: Applying to Graduate School [PDF]. Boston: Boston College. Retrieved April 1, 2017 , from https://www.bc.edu/content/dam/files/offices/careers/pdf/gradschool.pdf

Erdoğmuş, F. U. (2009). Research trends in CEIT MS and PhD theses in Turkey: A content analysis (Unpublished master's thesis). Middle East Technical University, Ankara, Turkey.

Feiman-Nemser, S. (1989). Teacher preparation: Structural and conceptual alternatives (Issue Paper 89-5). East Lansing: Michigan State University, National Center for Research on Teacher Education. Retrieved from https://files.eric.ed.gov/fulltext/ED312261.pdf

Foshay, A.W. (1991). The Curriculum matrix: transcendence and mathematics. Journal of Curriculum and Supervision. 6(4), 277-93.

Fraenkel, J. R., Wallen, N. E., \& Hyun, H. H. (2012). How to design and evaluate research ( ${ }^{\text {th }}$ Ed.). New York, NY: McGraw-Hill.

Frankel, J. R., Wallen, N. E. (1993). How to design and evaluate research in education ( $2^{\text {nd }}$ Ed.). New York, NY: McGraw-Hill.

Göktaş, Y., Hasancebi, F., Varisoglu, B., Akcay, A., Bayrak, N., Baran, M., \& Sözbilir, M. (2012). Trends in Educational Research in Turkey: A Content Analysis. Educational Sciences: Theory \& Practice, 12(1), 443-460. Retrieved from https://files.eric.ed.gov/fulltext/EJ978453.pdf

Gazi University Graduate School of Education Science. (2016). Tarihçemiz. Retrieved April 1, 2017, from http://egtbil.gazi.edu.tr/posts/view/title/tarihcemiz-162597?siteUri=egtbil

Guha, S. (n.d.). Early Childhood Education, Master of Science in Education. Retrieved April 1, 2017, from https://www.stjohns.edu/academics/schools-and-colleges/school-education/programmes-andmajors/early-childhood-education-master-science-education\#

Haktanır, G., Dağlığlu, E., \& Güler, T. (2010). The situation of regular early childhood education in Turkey [PDF]. Ankara: UNESCO National Committee of Turkey.

Hännikäinen, M. (2010). 1 to 3-year-old children in day care centers in Finland: An overview of eight doctoral dissertations. International Journal of Early Childhood. 24(2), 101-115. https://doi.org/10.1007/s13158010-0015-5

Hanson, B. (1973). Trends and problems in comparison studies of early childhood education models. Washington, D.C: National Inst. of Education (DHEW). Retrieved from https://files.eric.ed.gov/fulltext/ED092241.pdf

Hart, C. (1998). Doing a literature review: Releasing the social science research imagination. London: Sage Publications.

Jin, Y. (2004). The development of the China networked digital library of theses and dissertations. Online Information Review, 28(5), 367-370. https://doi.org/10.1108/14684520410564299

Kaytez, N., \& Durualp, E. (2014). An overview of postgraduate theses within the field of play at early childhood education in Turkey. International Journal of Education Sciences, 2(2), 110-122. Retrieved from http://dergipark.gov.tr/download/article-file/82097

Lee, S. (2012). Tracing the transformation of early childhood music education in young children from 1985 to 2010. Visions of Research in Music Education, 22(1), 1-25.

May, K. M., \& Holzemer, W. L. (1985). Master's thesis policies in nursing education. Journal of Nursing Education, 24(1), 10-15. 
McLean Davies, L., Anderson, M., Deans, J., Dinham, S., Griffin, P., Kameniar, B., \& Tyler, D. (2012). Masterly preparation: embedding clinical practice in a graduate pre-service teacher education programmeme. Journal of Education for Teaching, 39(1), 93-106. https://doi.org/10.1080/02607476.2012.733193

Ministry of National Education. (2014). Millî eğitim bakanlığı okul öncesi eğitim ve ilköğretim kurumları yönetmeliği. Retrieved from http://mevzuat.meb.gov.tr/html/ilkveokuloncyon_0/yonetmelik.pdf

Novak, R. S. (1975). A descriptive analysis of dissertations in the Department of Education, North Texas State University (Unpublished Doctoral dissertation). North Texas State University, Denton, Texas.

Ölçme Seçme ve Yerleştirme Merkezi (ÖSYM) (2016). 2016 Öğrenci Seçme ve Yerleştirme Sistemi yükseköğretim programmeları ve kontenjanları kılavuzu. Retrieved from http://dokuman.osym.gov.tr/pdfdokuman/2016/LYS/TERCIH/OSYSKONTKILAVU ZU18072016.pdf

Polat, M. (2013). A research into completed post-graduate theses in the field of physical science: Celal Bayar University sample. Journal of Buca Faculty of Education, 35(2), 46-58. Retrieved from http://dergipark.gov.tr/download/article-file/231555

Prasad, B. D, (2008). Content analysis: A method of Social Science Research, In D.K. Lal Das (ed.), Research Methods for Social Work (pp.174-193), New Delhi: Rawat Publications.

Rone, E. C. (1998). Characteristics of higher education doctoral theses: Defrosting frozen assets (Unpublished doctoral dissertation). University of Toronto: Toronto, Canada.

Rule, P. (2011). On the right and left of the centre: ABET and ECE postgraduate educational research in South Africa, 1995-2004. South African Journal of Higher Education, 25(2), 322-340.

Targonski, R. (2003). If you want to study in the United States. US Department of State: Bureau of Educational and Cultural Affairs. Retrieved from http://exchanges.state.gov/education/educationusa/

Taştepe. T., Öztürk-Serter, G., Yurdakul, Y., Taygur-Altıntaş, T., \& Bütün-Ayhan, A. (2016). The analysis of postgraduate theses about inclusion in preschool period in Turkey. The Journal of Academic Social Science Studies. 49, 501-514.

The National Institute for Early Education Research. (2017). Master of Education in Curriculum and Instruction (Early Childhood Education) Student Handbook Fall 2017 [Brochure]. Rutgers Graduate School of Education. Retrieved April 1, 2017.

The Worldwatch Institute. (2017). EarthEd (State of the World). Washington: Island Press.

Weber, R. P. (1990). Basic content analysis ( $2^{\text {nd }}$ Ed.). Beverly Hills, CA: Sage University Papers

Yavuz, S. (2016). A Content analysis related to theses in environmental education: The case of Turkey (20112015). Journal of Education and Training Studies, 4, 118-125. https://doi.org/10.11114/jets.v4i10.1794

Yıldırım, A., \& Şimşek, H. (2011). Sosyal bilimlerde nitel araştırma yöntemleri (8· Ed.). Ankara: Seçkin Yayınları.

Yıldız, A. (2004). Türkiye'deki yetişkin eğitimi araştırmalarına toplu bakış. Ankara Üniversitesi Ë̆itim Bilimleri Fakültesi Dergisi. 37(1), 78-97. Retrieved from http://dergipark.gov.tr/download/article-file/509206

The Higher Education Law No. 2547. (1981, November 6). Retrieved from http://www.resmigazete.gov.tr/arsiv/17506.pdf

Yükseköğretim Kurulu. (2017). Yükseköğretim bilgi yönetim sistemi. Yükseköğretim İstatistikleri. Retrieved from https://istatistik. yok. gov. tr/yuksekogretimIstatistikleri/2016/2016_T17.pdf

Zhang, Q. (2015). The voice of the child in early childhood education research in Australia and New Zealand: A systematic review. Australasian Journal of Early Childhood, 40(3), 97-104. 


\section{TÜRKÇE GENIȘLETILMIŞ ÖZET}

Mevcut çalışma, erken çocukluk eğitimi alanında çalışan bilim insanlarının oluşturduğu lisansüstü çalışmaların kapsamlı bir alan yazın taramasını içerir. Sonuçlar, erken çocukluk eğitiminde yapılmış lisansüstü çalışmalarda hangi konuların iyi sunulduğunu, hangilerinin ise hak ettiği kadar çalışılmadığını ortaya koyacaktır. Ayrıca, bu çalışmanın bulguları mevcut metodolojik ve istatistiksel eğilimlerle ilgili bilgi sağlayacaktır. Sonuçlar seçili zaman aralığındaki erken çocukluk eğitimi üzerine yapılan çalışmalardaki eğilim değişimini gözlemleme şansı sunacaktır.

Çalışmada, erken çocukluk eğitimi üzerine yazılmış lisansüstü çalışmaların betimleyici ve içerik özelliklerinin, Türkiye'de alanın durumuna ilişkin kapsamlı bir resim çizebilmek adına incelenmesi amaçlanmaktadır. Ayrıca, bu çalışma tezlerin metodolojilerini de, kullanılan araştırma yöntemleri ve istatistiksel tekniklere bağlı olarak tercih edilen araştırma eğilimlerini ortaya koymak amacıyla incelemektedir. Çalışmanın araştırma soruları şu şekildedir;

1. Türkiye'de erken çocukluk eğitimi üzerine yazılmış yüksek lisans ve doktora tezlerinin betimleyici özellikleri (üniversite, enstitü, bölüm, yayımlanma tarihi, tezin dili ve danışmanın akademik unvanı) nelerdir?

2. Türkiye'de erken çocukluk eğitimi üzerine yazılmış yüksek lisans ve doktora tezlerinin içerik özellikleri (araştırma konusu) nelerdir?

3. Türkiye'de erken çocukluk eğitimi üzerine yazılmış yüksek lisans ve doktora tezlerinin metodolojik özellikleri (çalı̧̧ma grubu, çalışmanın gerçekleştirildiği alan, araştırma yöntemi, araştırma deseni, veri toplama araçları, istatistiksel analiz ve örneklem yöntemleri) nelerdir?

Çalışmada nitel araştırma desenlerinden içerik analizi kullanılmıştır. Doküman analizinin veri toplama yöntemi olarak kullanıldığg çalışmada, yüksek lisans ve doktora tezleri, doküman analizi sürecinde bilgi kaynaği olarak kullanılmıştır. Veri analizi süreci için, içerik analizi metodu tercih edilmiştir. Veri toplama sürecinde toplam 1494 lisansüstü tez incelenmiş ve erişime açık 1986-2016 yılları arasında erken çocukluk eğitimi üzerine yazılmış 1102 tez, çalışmanın örneklemi olarak belirlenmiştir. Araştırmacılar, ilgili alan yazın ve benzer lisansüstü tezlere dayalı olarak oluşturulmuş bir sınıflandırma geliştirmiştir. Çalışmanın geçerliği; görünüş geçerlik, dış geçerlik ve kapsam geçerliği açısından incelenmiştir. İlk olarak, görünüş geçerliği ele alınmıştır. Mevcut çalışmada; araç, araştırmacılar tarafından geliştirilmiştir ve ilgili alan yazın ile benzer çalışmalar bu aracın inşa sürecinde değerlendirilmiştir. Araştırmacılar, ayrıca ilk taslaktan sonra erken çocukluk eğitimi alanında çalışan bir öğretim üyesinden uzman tavsiyesi almıştır. Uzman görüşü üzerinden, araç revize edilmiş, aracın son hali bir pilot çalışma ile oluşturulmuştur. Pilot çalışmanın sonunda, araç amaçlanan ölçümü yapabilmesi nedeniyle geçerli kabul edilmiştir. Ardından, aracın dış geçerliği kontrol edilmiştir. Bu çalışmanın popülasyonu Türkiye'de erken çocukluk eğitimi üzerine yazılmış tüm lisansüstü tezleri içermektedir ve haliyle tüm tezlere erişmek neredeyse imkânsızdır. Bu nedenle, yalnızca çevrimiçi tam erişime açık olan tezler çalışmaya dâhil edilmiştir. Sonrasında, içerik geçerliğinden emin olmak adına içerik analizi çalışmaları yürüten iki farklı araştırma görevlisi Tez İnceleme Formunu gözden geçirmiştir. Son olarak, çalışmanın güvenirliğinden de emin olunmuştur. Mevcut çalışmada, güvenilir sonuçlar elde edebilmek için hem kodlayıcılar arası tutarlılık hem de test-yeniden test teknikleri uygulanmıştır. Kodlayıcılar arası tutarlılık Cohen's Kappa yöntemi ile ölçülmüştür. Mevcut çalışmanın Kappa değeri 0,86 olarak hesaplanmıştır ki, bu kodlayıcılar arasında yeterli bir tutarlılık oranına işaret eder. Test-yeniden test güvenirliği için, birinci kodlamayı takip eden sekizinci haftada, başka bir kodlayıcı kodlama sürecini yeniden uygulamıştır. 
Elde edilen bulgulara göre, erken çocukluk eğitimine ilişkin lisansüstü çalışmalar yalnızca erken çocukluk eğitimi bölümlerinde yayınlanmamıştır. Türkiye'de erken çocukluk eğitimine ilişkin yüksek lisans tezleri, çocuk sağlı̆̆ ve eğitimi bölümlerinde 1989 yılında yayımlanmaya başlamıştır. Bu alandaki ilk doktora tezi ise 1993 yılında mimarlık bölümünde yazılmıştır. İlk erken çocukluk eğitimi lisansüstü programmeı 1993 yılında açılmış, erken çocukluk eğitimi bölümünün ilk tezi ise 1996 yılında yayımlanmıştır. Lisansüstü tez üreten üniversiteler incelendiğinde bazı üniversitelerin başı çektiği görülecektir. Marmara ve Gazi Üniversiteleri en üretken üniversiteler olup, ardından Ankara Üniversitesi, Orta Doğu Teknik Üniversitesi ve Selçuk Üniversitesi gelmektedir. Mevcut çalışmanın sonuçları; erken çocukluk eğitimi, çocuk gelişimi ve eğitimi bölümlerinin erken çocukluk eğitimi üzerine lisansüstü tez üretmek konusunda en üretken bölümler olduğunu göstermiştir. Ancak, lisansüstü tezlerin çoğunluğu erken çocukluk eğitimi programmelarında yazılmıştır. Oysa ki, geçmiş çalışmaların bulguları, çocuk gelişimi ve eğitimine ilişkin tezlerin sayısının erken çocukluk eğitimi üzerine yazılmış lisansüstü tezlerden daha fazla olduğunu göstermiştir.

Lisansüstü tezlerin konularına ilişkin bulgular göstermiştir ki; eğitim, gelişme ve öğretmen/yönetici konularını işleyen tezler, erken çocukluk eğitimi yüksek lisans seviyesinde en yaygın araştırma konuları olmuştur. Doktora tezlerinde ise araştırmacılar çoğunlukla gelişim $(\% 32,78)$, eğitim $(\% 30,77)$ ve öğretim yöntemleri $(\% 11,71)$ üzerine çalışmıştır. Yüksek lisans tezlerinde olduğu gibi, sosyal-duygusal gelişim, özellikle sosyal beceriler, erken çocukluk eğitimi alanında en çok çalışılan konular olmuştur.

Mevcut çalışmanın sonuçları, çocukların/öğrencilerin hem yüksek lisans hem de doktora tezlerinde en sık çalışılan örneklem grubu olduğunu göstermiştir ki bu beklenen bir bulgudur. Ancak, örneklemlerin yaş grupları incelendiğinde neredeyse tüm lisansüstü tezlerin üç-altı yaş arasındaki çocuklara odaklandığı görülmüştür. Sıfir-üç yaş arasındaki çocuklar ise lisansüstü tezlerde en az çalışılan yaş grubu olmuştur.

Bu çalışmada, Türkiye'de erken çocukluk eğitimi üzerine yazılmış, çevrimiçi ve erişime açık tüm lisansüstü tezleri incelemiştir. İleriki çalışmalarda, Türkiye'de erken çocukluk eğitimi üzerine yazılmış dergi makaleleri, betimsel özellikleri, kavramsal bilgileri ve metodolojik özellikleri açısından incelenebilir. 